\title{
Inner-shelf circulation and sediment dynamics on a series of shoreface-connected ridges offshore of Fire Island, NY
}

\author{
John C. Warner • Jeffrey H. List • William C. Schwab • \\ George Voulgaris $•$ Brandy Armstrong $•$ Nicole Marshall
}

Received: 13 January 2014 / Accepted: 6 October 2014 / Published online: 24 October 2014

(C) The Author(s) 2014. This article is published with open access at Springerlink.com

\begin{abstract}
Locations along the inner-continental shelf offshore of Fire Island, NY, are characterized by a series of shorefaceconnected ridges (SFCRs). These sand ridges have approximate dimensions of $10 \mathrm{~km}$ in length, $3 \mathrm{~km}$ spacing, and up to $\sim 8 \mathrm{~m}$ ridge to trough relief and are oriented obliquely at approximately $30^{\circ}$ clockwise from the coastline. Stability analysis from previous studies explains how sand ridges such as these could be formed and maintained by storm-driven flows directed alongshore with a key maintenance mechanism of offshore deflected flows over ridge crests and onshore in the troughs. We examine these processes both with a limited set of idealized numerical simulations and analysis of observational data. Model results confirm that alongshore flows over the SFCRs exhibit offshore veering of currents over the ridge crests and onshore-directed flows in the troughs, and demonstrate the opposite circulation pattern for a reverse
\end{abstract}

Responsible Editor: John C. Warner

J. C. Warner $(\bowtie) \cdot$ J. H. List $\cdot$ W. C. Schwab $\cdot$ B. Armstrong

Coastal and Marine Geology Program, U.S. Geological Survey, 384

Woods Hole Road, Woods Hole, MA 02543, USA

e-mail: jcwarner@usgs.gov

J. H. List

e-mail: jlist@usgs.gov

W. C. Schwab

e-mail: bschwab@usgs.gov

B. Armstrong

e-mail: barmstrong@usgs.gov

G. Voulgaris

Marine Science Program, Department of Geological Sciences,

University of South Carolina, Columbia, SC 29208, USA

e-mail: gvoulgaris@geol.sc.edu

N. Marshall

College of William and Mary, Virginia Institute of Marine Science, Gloucester Point, VA 23062, USA

e-mail: nrmarshall@vims.edu wind. To further investigate these maintenance processes, oceanographic instruments were deployed at seven sites on the SFCRs offshore of Fire Island to measure water levels, ocean currents, waves, suspended sediment concentrations, and bottom stresses from January to April 2012. Data analysis reveals that during storms with winds from the northeast, the processes of offshore deflection of currents over ridge crests and onshore in the troughs were observed, and during storm events with winds from the southwest, a reverse flow pattern over the ridges occurred. Computations of suspended sediment fluxes identify periods that are consistent with SFCR maintenance mechanisms. Alongshore winds from the northeast drove fluxes offshore on the ridge crest and onshore in the trough that would tend to promote ridge maintenance. However, alongshore winds from the southwest drove opposite circulations. The wind fields are related to different storm types that occur in the region (low-pressure systems, cold fronts, and warm fronts). From the limited data set, we identify that low-pressure systems drive sediment fluxes that tend to promote stability and maintain the SFCRs while cold front type storms appear to drive circulations that are in the opposite sense and may not be a supporting mechanism for ridge maintenance.

Keywords Shoreface-connected ridges - Sediment transport . Fire Island, NY · Storm fronts · Oceanographic observations · Numerical modeling

\section{Introduction}

Fire Island is part of a barrier island system along the southern shore of Long Island, NY, bounded by Fire Island Inlet to the west and Moriches Inlet to the east (Fig. 1). The barrier island itself provides a natural defense from the impacts of waves and large storm events for the densely developed mainland. 
Fire Island is $0.5-1 \mathrm{~km}$ wide and contains many different (and sometimes conflicting) land uses such as the Fire Island National Seashore, State Parks, a Federal Wilderness Area, and a number of coastal communities. Sections of Fire Island have high rates of coastal erosion, while others are relatively stable (Hapke et al. 2010; Schwab et al. 2013). A principal strategy to mitigate coastal erosion is construction of sand berms, dunes, and regular beach nourishments, with sediment dredged from the adjacent inner-continental shelf. Remnant borrow locations are visible in the bathymetric data (Fig. 1). However, it is not well understood how changes to these adjacent inner-continental shelf locations can potentially impact the nearshore coastal region. A recent sediment budget analysis (Schwab et al. 2013) concluded that a cross-shore sediment flux is required to close the budget and identifies that the inner shelf is a likely source.

Previous studies have characterized the shallow geologic framework on the inner-continental shelf offshore of Fire Island (Schwab et al. 2013 and references therein). The eastern section of the study area is characterized with a uniformly sloping inner shelf. In contrast, the western section of the inner shelf contains a series of sedimentary (sandy) features referred to as shoreface-connected ridges (SFCRs). Between these sections is a submerged headland consisting of a glaciofluvial outwash lobe. It is inferred that erosion of the outwash lobe during the latest marine transgression yielded an abundance of sedimentary material which has been transported westward to supply the development the SFCRs west of Watch Hill (Schwab et al. 2013).

These SFCRs vary in size and configuration but are in general on the order of $10 \mathrm{~km}$ in length, have a crest to trough relief as high as $\sim 8 \mathrm{~m}$, are spaced about $3 \mathrm{~km}$ apart, are a maximum of $5 \mathrm{~m}$ thick, and are oriented oblique from the coastline on average about $30^{\circ}$ clockwise. The existence of shoreface-connected ridges - also known as shore-attached shoals - on the eastern coast of the USA was first documented in the early 1970s (Duane et al. 1972; Swift et al. 1972). Similar ridges are found elsewhere in the world, such as the Brazilian Shelf (Figueiredo et al. 1982), the Argentinian Shelf (Parker et al. 1982), the Canadian Continental Shelf (Hoogendoorn and Dalrymple 1986), and the central Dutch and European Shelves (van de Meene 1994; Swift et al. 1978).

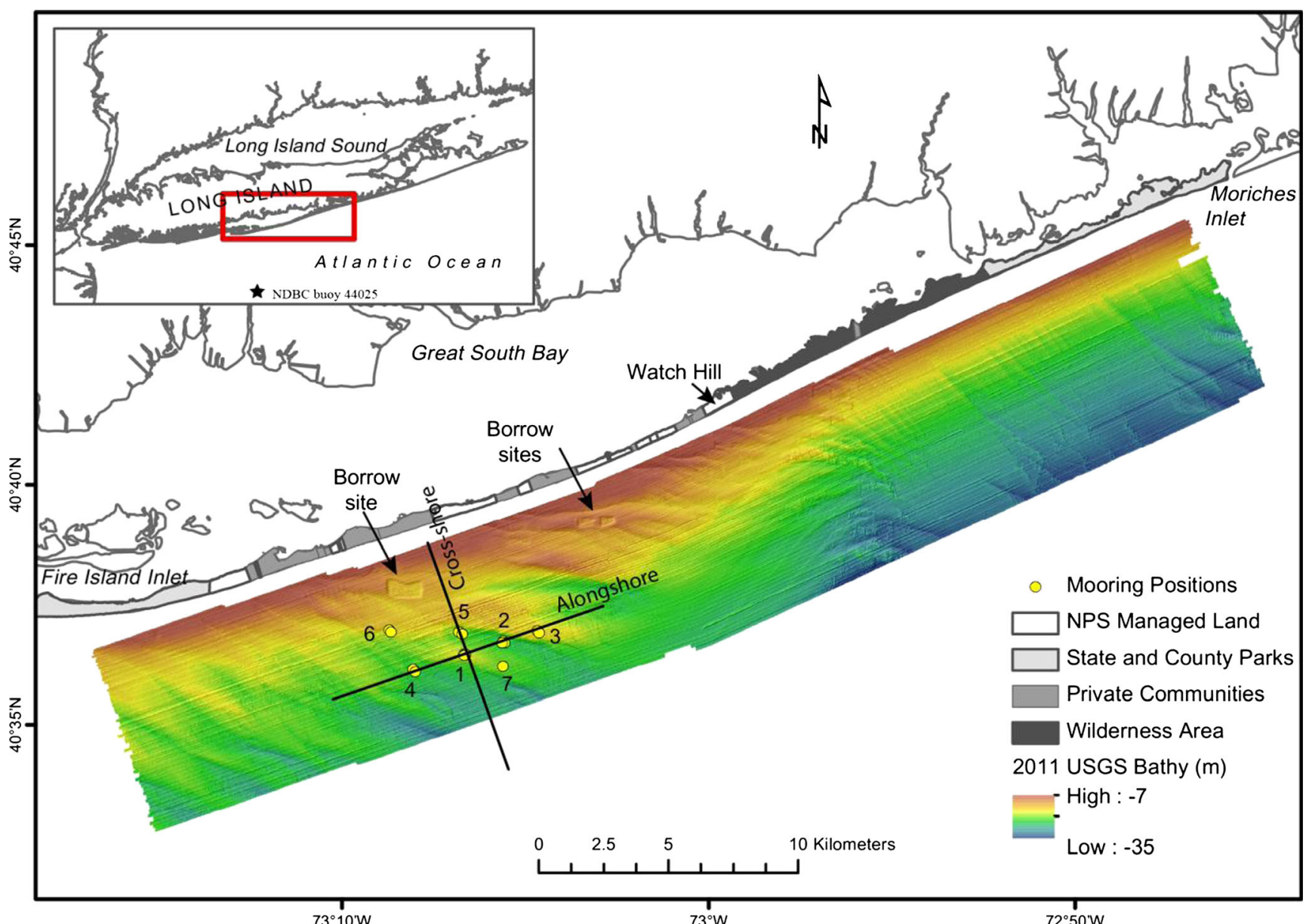

Fig. 1 Study area site map. Inset shows Long Island, NY, and location of NDBC buoy 44025. Main map identifies several land uses along Fire Island with color shading of recent bathymetry (Schwab et al. 2013)

showing the SFCRs on the western side and a more planar shelf on the eastern side. Sand borrow sites are visible in the SFCRs and numbered circles show locations of deployment sites 
All of these sand ridges exist in areas where there are significant flows due either to tidal, wind-driven, or a combination of forcings. It is also characteristic that in all these cases, the ridges are oriented at an oblique angle to the flow and coastline.

Huthnance (1982) was one of the first to combine depthaveraged hydrodynamics with sediment transport to explain the formation of flow-oblique sand bodies; however, that analysis was focused on the generation of sand banks on the tide-dominated environment of the southern North Sea and was not able to account for the rotation of SFCR crests in relation to the coastline. Later, Trowbridge (1995) presented a stability analysis model for the generation and maintenance of shore-attached shoals like those found along the eastern US coastline. According to his theory, these shoals are the result of offshore deflection of alongshore storm-induced flows over a topographic disturbance into deeper water. As the flows are deflected offshore, the presence of a shelf slope will cause the flows to decrease in deeper water and the sediment fluxes will converge and create deposition on ridge crests.

Falques et al. (1998) described a morphodynamic model that also included Coriolis and bottom friction to gain a more fundamental understanding of the physical mechanisms for the SFCR characteristics. They identified a positive feedback of offshore deflection of currents over the ridge crests, creating flow convergence that leads to sediment deposition and hence ridge growth. They also identified that flow in the opposite direction would lead to onshore deflection of the currents, which is not in the direction to promote ridge growth. Other linear instability analysis (Calvete et al. 2001a, b) has been used to explain the generation of such features under a variety of forcing conditions. Calvete et al. (2001b) numerically demonstrated that development (i.e., growth rate and orientation) and scales of these features depend on the nature of the oscillatory vs. non-oscillatory (i.e., tidal and winddriven) forcing and presented an analysis for stormdominated conditions, fair weather conditions, and a mixture of both. The main difference between the storm and fair weather condition case was the sediment transport parameterization as a function of the instantaneous velocity, which was assumed linear for the storm case and cubic for the fair weather case. During storms, the waves suspend the sediment and the steady, wind-driven current transports it away, while during fair weather conditions, the majority of the sediment is moved as bedload. When dominated by storm conditions, the ridge axes have their seaward ends directed upstream into the steady current. For fair weather ridges, Calvete et al. (2001b) found that the relative magnitude of the steady, wind-driven alongshore flow relative to the tidal flow only weakly affects ridge development. Also, over fair weather ridges, the tidally averaged flow tends to be offshore on the landward side of the ridge and onshore on the offshore edge, while stormdominated ridges are characterized by subtidal flows that cross over the crest of the ridge (Calvete et al. 2001b). In terms of length scales, three instability regimes were identified: (1) wind-driven flows dominating the signal, yielding predicted lengths of the shoals on the order of $3 \mathrm{~km}$; (2) winddriven flows in balance with the tidal forcing, yielding shoal lengths on the order of $8 \mathrm{~km}$; and (3) tidal flows dominating the signal, resulting in shoal lengths on the order of $10 \mathrm{~km}$.

Additional investigations have focused on sediment sorting on the SFCRs (Walgreen et al. 2003), effects of waves on bottom stress variations across the ridges (Vis-Star et al. 2007), and effects of wave-current interactions on bedform instabilities (Lane and Restrepo 2007). The combined effect of waves and currents can create processes that vary at scales similar to those of the ridges themselves. Recent investigations by Nnafie et al. (2014a) examined the response of SFCRs to sand extraction on the ridges themselves. Numerical modeling results indicated that the SFCRs partially restore but never reach the same state as ridges that did not have extraction. Nnafie et al. (2014b) also examined the effects of sea level rise on SFCR processes and interactions between rates of sea level rise and inner shelf bottom slope. More details on additional studies pertaining to nonlinear evolution of SFCRs can be found in Nnafie et al. (2014a).

The research presented here is part of a larger effort to better understand coastal processes in the study region that include: (i) establishment of an accurate coastal sediment budget for the area, (ii) understanding the impacts to the coastal system if the ridges are mined as a source for beach nourishment, and (iii) the effect of the ridges in modifying the wave energy delivered to the coastline. As a first part of that larger effort, the primary goal of this paper is to further the understanding of the processes on the sand ridges themselves by focusing on the way they interact with the wind-driven flow and how are these features maintained. Section 2 describes results of oceanographic circulation from a hydrodynamics-based model applied to an idealized ridge system of a scale similar to that found in Fire Island. At this stage, we use an idealized ridge system and we do not examine the effect of waves as this is the subject of subsequent studies. Section 3 examines observations of ocean currents from a field deployment on the SFCRs offshore of Fire Island to test for the presence of key-specific flow processes which are central to the development and maintenance of the ridge system. Section 4 discusses the comparison of the model to observations and describes the sediment dynamics observed on the sand ridges. Conclusions are presented in Section 5.

\section{SFCR modeling}

To investigate the processes of ocean circulation across SFCR features, we first utilize a numerical modeling system to characterize the flows on an idealized ridge-trough system 
that is representative of the bathymetric configuration offshore of Fire Island. We used the Regional Ocean Modeling System (ROMS), a three-dimensional, free-surface, topography following numerical model, which solves finite difference approximations of Reynolds Averaged Navier Stokes (RANS) equations using hydrostatic and Boussinesq approximations with a split-explicit time-stepping algorithm (Shchepetkin and McWilliams 2005, 2009; Haidvogel et al. 2008). ROMS includes options for various model components such as different advection schemes (second, third, and fourth order), turbulence closure models (e.g., generic length scale mixing, Mellor-Yamada, Brunt-Väisälä frequency mixing, user provided analytical expressions, K-profile parameterization), and several options for boundary conditions.

We use an idealized setup with a repeated ridge bathymetry that will allow the flow field to develop and be easily discerned over the features. The idealized numerical grid was $25 \mathrm{~km}$ in the alongshore $(x-)$ direction and $6 \mathrm{~km}$ in the cross-shore (y-) direction (Fig. 2a) and discretized at $100 \mathrm{~m}$ grid spacing leading to a domain with 250 cells in the $x$ - and 60 cells in the $y$ - directions. The model bathymetry consists of a repeated ridge that has $8 \mathrm{~m}$ of relief at the shallow landward end and tapers to blend with the flat shelf at $20 \mathrm{~m}$ depth in the offshore (negative $y$-) direction. Ridges are angled $30^{\circ}$ clockwise from the shoreline, set to be $10 \mathrm{~km}$ long, and repeated every $3 \mathrm{~km}$, for a total of five ridges. Although there is a slope along the crest of the ridges, for the purposes of simplicity, the background bathymetry is horizontal. This assumption allows us to enhance the differences in flow between the crests and troughs and allows us to easilyidentify the dominant processes. Model simulations were performed with 12 vertical levels and a uniform density. Initial conditions were a horizontal water surface and the flows at rest. Two simulations were performed, each with an imposed 0.4 Pa surface stress (approximately a $15-\mathrm{ms}^{-1}$ wind speed) in the $x$-direction: one in the $+x$ and one in the $-x$ direction. Lateral boundary conditions were periodic, and the simulation was bounded by a northern wall to represent a shoreline and a constant gradient condition along the southern offshore boundary. The surface stress forcings were allowed to slowly ramp up in time and then maintain a constant stress until the flows developed in a steady-state solution. The effects of waves were not included in these simulations.

Results identify that for a surface stress in the negative $x$ direction (Fig. 2b), a flow pattern develops with currents flowing uniformly over the shelf. Figure $2 b$ shows the
Fig. 2 Numerical simulations. a Model grid showing every second grid line with bathymetry shading. b Model results using surface stress in negative $x$ direction with arrows showing currents deflecting offshore over ridge crests and onshore in the troughs. c Similar to (b) but surface stress in positive $x$ direction and currents show opposite pattern. Note expanded aspect ratio for (b) and (c)

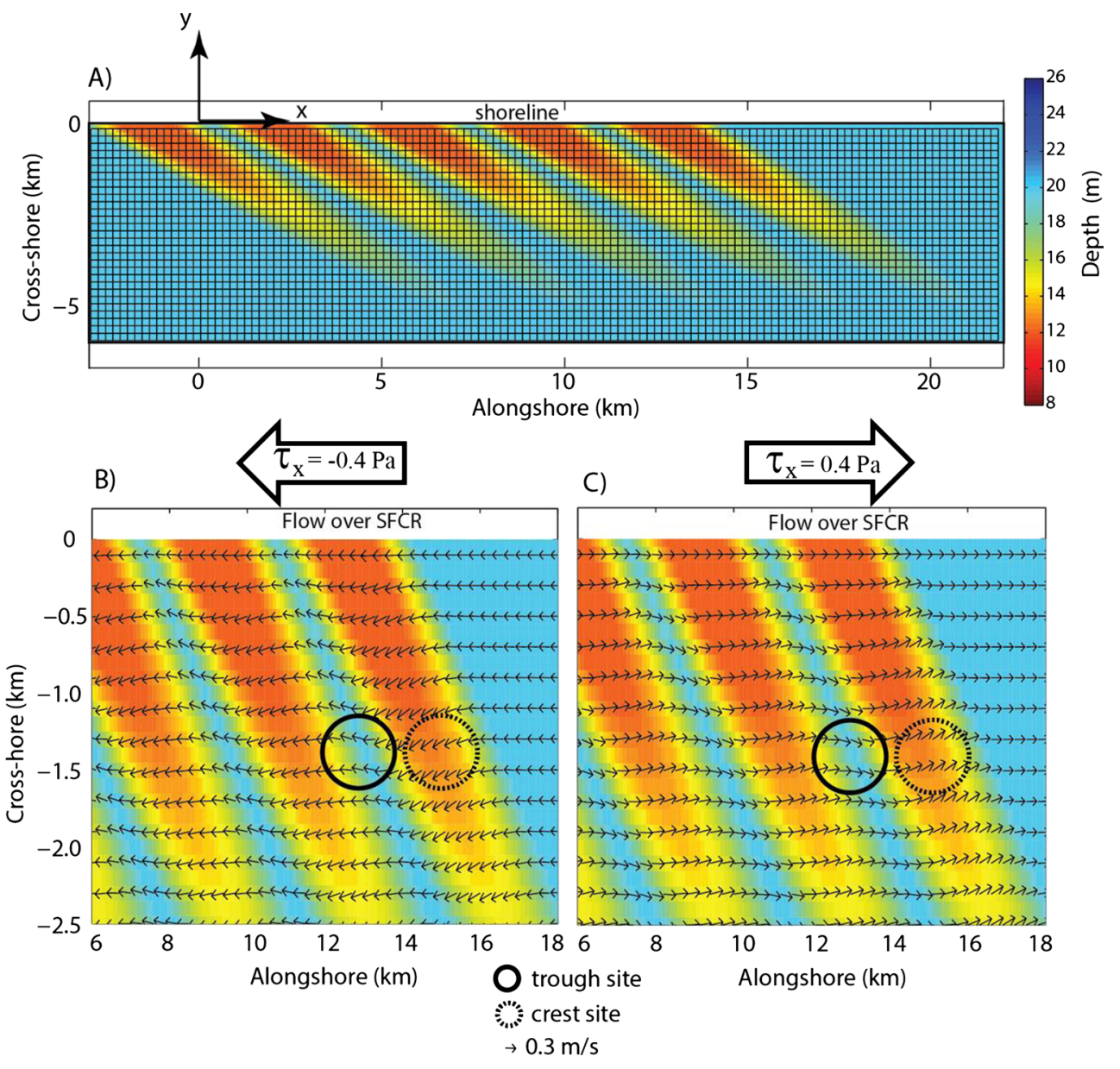


depth-averaged currents, but the flows are consistent throughout the water column. As the flow encounters the ridges, the currents are deflected offshore over the ridge crests (location of a dotted circle) and onshore in the troughs (location of the solid border circle). This is consistent with what has been shown in previous linear stability analysis theory as described previously. The magnitude of the alongshore currents are on the order of $0.30 \mathrm{~ms}^{-1}$, and the cross-shore currents are weaker near $0.03 \mathrm{~ms}^{-1}$. When the surface stress is reversed, the flow on the flat portion of the shelf is again uniform in the direction of the stress, but over the ridges, the flow pattern is reversed and deflected onshore on the crests and offshore in the troughs (Fig. 2c). These flow patterns are being demonstrated for surface stresses in opposite directions for comparison to the observations shown in Section 3.

To determine the balance that governs the flows, the numerical diagnostics are used to identify the main terms in the momentum balance (Fig. 3). In a simplified depth-averaged sense, the momentum balances in the alongshore (Eq. 1) and cross-shore (Eq. 2) directions can be expressed as follows:

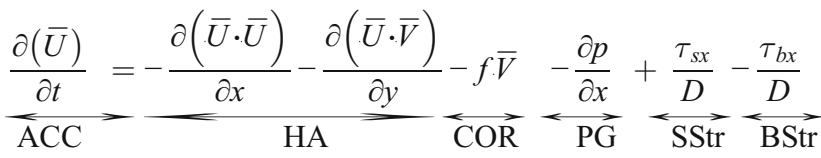

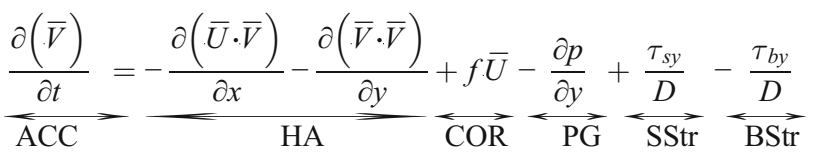

where the subscripts $x$ and $y$ represent the horizontal coordinates, with $\bar{U}$ and $\bar{V}$ are depth-averaged mean velocities, $D$ is the total water depth, $f$ is the Coriolis parameter, $p$ is the total barotropic pressure, and $\tau_{\mathrm{s}}$ and $\tau_{\mathrm{b}}$ are surface and bottom stresses, respectively. Because the flow developed to a steady state response, the temporal acceleration terms (ACC) are negligible. The Coriolis parameter $(f)$ was set at $9.5 \times$ $10^{-5} \mathrm{~s}^{-1}$ for a northern near $40^{\circ}$ latitude value near Long Island, NY.

The momentum balance terms are shown in Fig. 3 for the case with the surface stress in the negative $x$-direction. The momentum balance is computed with all terms on the righthand side except the ACC term, as shown in Eqs. 1 and 2. In the alongshore direction, the dominant momentum terms are the bottom stress (BStr), surface stress (SStr), horizontal accelerations (HA), and the pressure gradient (PG) (Fig. 3a-d). The Coriolis acceleration (COR) term (Fig. 3e) is near zero for the alongshore balance. The significant terms demonstrate that in the alongshore direction, accelerations from the wind- induced surface stress are primarily in balance with the bottom stress. In addition, as the flow spatially accelerates over the shoals, the horizontal acceleration terms become significant. These flow divergences expressed by the HA terms create pressure gradients due to the setdown of the water level on the ridge crests and increases in the troughs.

In the cross-shore $(y$-) direction, there is no surface stress imposed (Fig. 3g) and so this term is zero; also, the BStr term (Fig. 3f) is small because the cross-shore velocities are small. The significant terms are the HA, PG, and COR (Fig. 3h-j). The offshore-directed flow is being driven by the mean PG term which is primarily in balance with the onshore flows driven by the COR term. Variations exist in the COR term, but they are not significant. However, over the ridges, the local flows are modified by the bathymetry and this is where the across-ridge variation of the PG term is reflected on the HA term as they balance each other. The HA is comprised of two terms: $-d(u v) / d x$ and $-d(v v) / d y$. Since the $-d(v v) / d y$ term is an order of magnitude smaller, over the ridges, the primary balance is between the $-\mathrm{d}(\mathrm{uv}) / \mathrm{dx}$ component of the HA and the PG term. Therefore, as the alongshore flows vary over the ridges, the cross-shore flows need to vary to maintain a balance with the PG term. These momentum balances show that the flow cannot accelerate to travel directly over the ridges. As the flow accelerates to travel up the ridges, gradients in transport require an offshore-directed flow for mass conservation. Similarly, as the flow decelerates on the downstream side of the ridges, gradients in transport require an onshore-directed flow for mass conservation. Therefore, variations in the alongshore flows should be important when investigating the cross-shore dynamics.

\section{SFCR observations}

This inner shelf offshore of Fire Island is a microtidal environment with a tidal range approximately $1.3 \mathrm{~m}$ at Fire Island Inlet (Leatherman 1985). Meteorological data from the National Data Buoy Center (NDBC) buoy 44025 (http:// www.ndbc.noaa.gov/station_page.php?station=44025; location shown in Fig. 1) for a 20-year period from 1993 to 2012 show that the winds are predominately from the southsouthwest, having speeds up to $10-15 \mathrm{~ms}^{-1}$ (Fig. 4a). Winds also occur from the west-northwest; they are less frequent but have greater speeds of up to $15-20 \mathrm{~ms}^{-1}$. Even less frequent winds occur from the northeast, but these winds also had higher speeds of up to $15-20 \mathrm{~ms}^{-1}$.

Oceanographic equipment was deployed offshore of Fire Island at seven sites for 4 months from January to April 2012. The experiment was mainly designed to measure the alongshore wind-driven flows, deflection of currents over the crests and troughs, and the ensuing sediment flux dynamics. These processes are considered to be the primary maintenance 
Fig. 3 Acceleration terms of the momentum balance in alongshore (left column) and cross-shore (right column) directions for wind blowing toward the left (negative $x$-direction). Panels a and $\mathbf{f}$ are the bottom stress, $\mathbf{b}$ and $\mathbf{g}$ are surface stress, $\mathbf{c}$ and $\mathbf{h}$ are horizontal accelerations, $\mathbf{d}$ and $\mathbf{i}$ are pressure gradient, and $\mathbf{e}$ and $\mathbf{j}$ are Coriolis acceleration terms
Alongshore direction
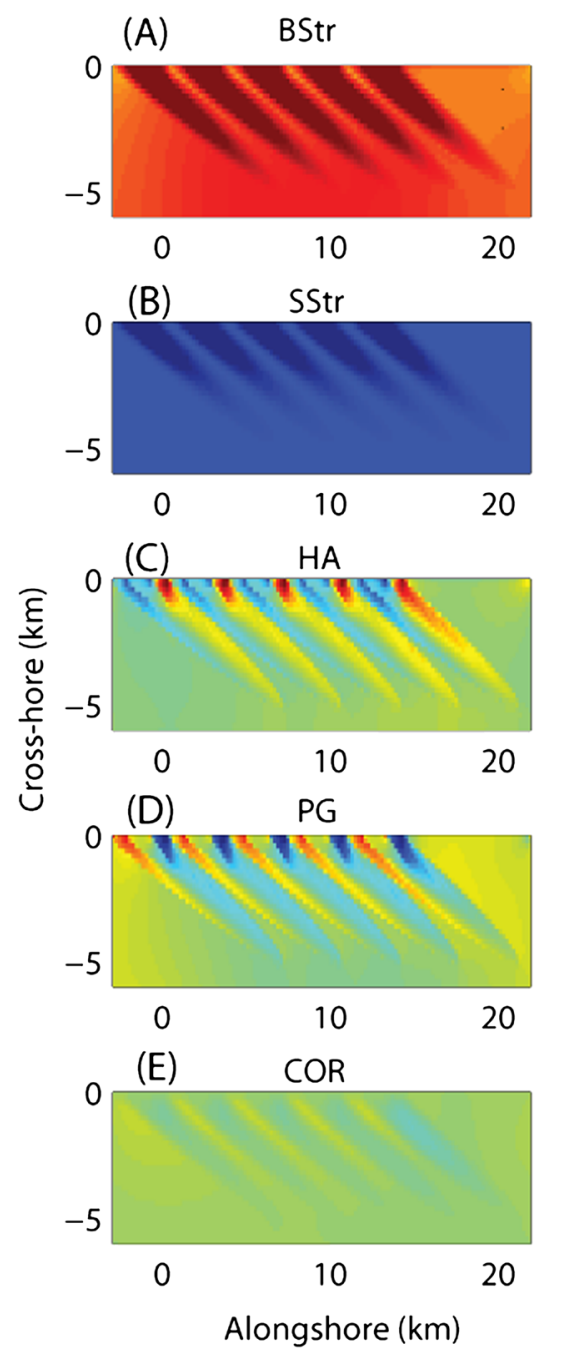

\section{Cross-shore direction}
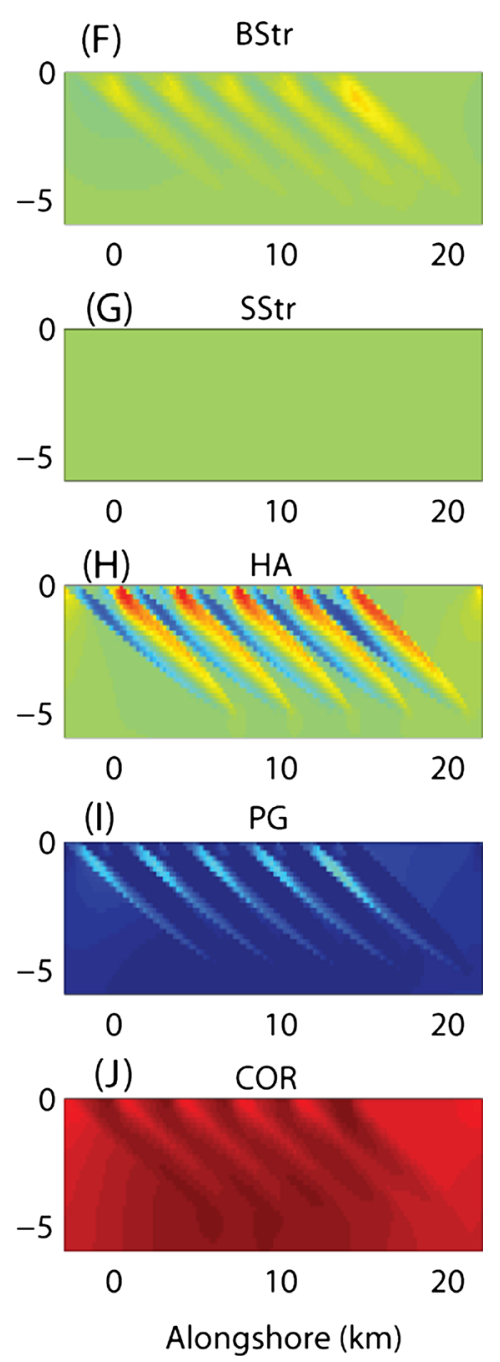

mechanisms of the ridges. The deployment consisted of seafloor tripods and surface floats (Fig. 1) located along a ridge crest (stations 6, 1, and 7) and along a line crossing several ridge crests and troughs (stations $4,1,2$, and 3 ). Site 5 was placed in the trough, further inshore than the other sites. The full experimental design is described in greater detail in Martini et al. (2012).

Instruments were deployed on tripods at each site to measure surface wave properties, water level, currents, temperature, and salinity. Tripods deployed at sites 1 and 2 also contained instrumentation dedicated to measuring near-bed sediment transport processes. These tripods consisted of downward-looking rotary sonars measuring bed forms (ripples) and were mounted approximately $0.5 \mathrm{~m}$ above the seafloor scanning the bed approximately every $6 \mathrm{~h}$, acoustic Doppler velocimeters (ADVs) to measure near-bottom turbulence, and multifrequency acoustic backscatter sensor (ABS) systems to measure suspended sediment concentrations. The
ABSs were calibrated in a $2-\mathrm{m}$ tall by $0.50-\mathrm{m}$ diameter recirculating tank equipped with a pneumatic diaphragm pump, located at the University of South Carolina. Because the ABS was a multifrequency system, we utilize the response of the different frequencies to obtain information on both particle size and concentration. In order to do that, the ABS system constants for each frequency were estimated using a backscatter signal from glass spheres of well-known size and acoustic properties as described in Thorne and Hanes (2002) and Thorne and Campbell (1992). Additionally, a meteorological station was placed on the surface buoy at site 1 to measure wind speed, direction, and air temperature.

During the deployment, there were many minor storm events with winds predominately from the southwest, west, and northwest (Fig. 4b). The strongest events were from the west with winds from 15 to $20 \mathrm{~ms}^{-1}$. Unfortunately, the deployment only captured a few events with winds from the 


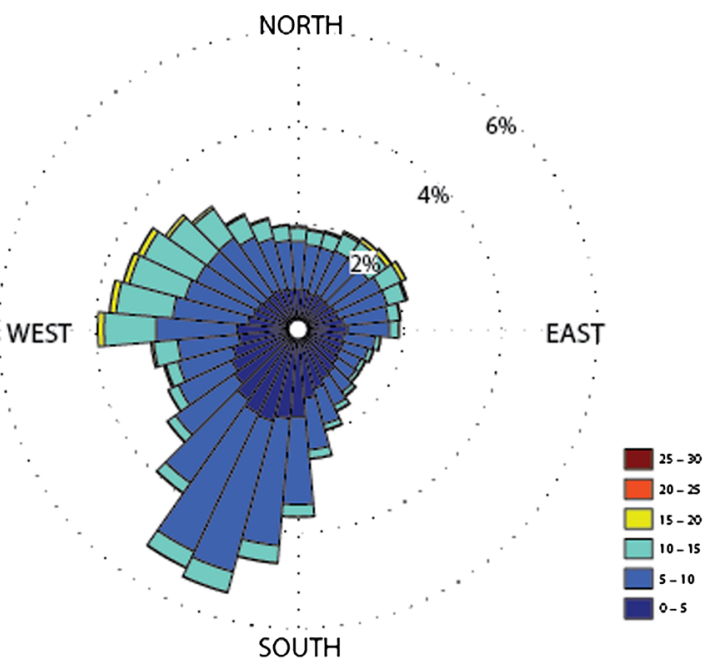

1993-2012 hourly wind data

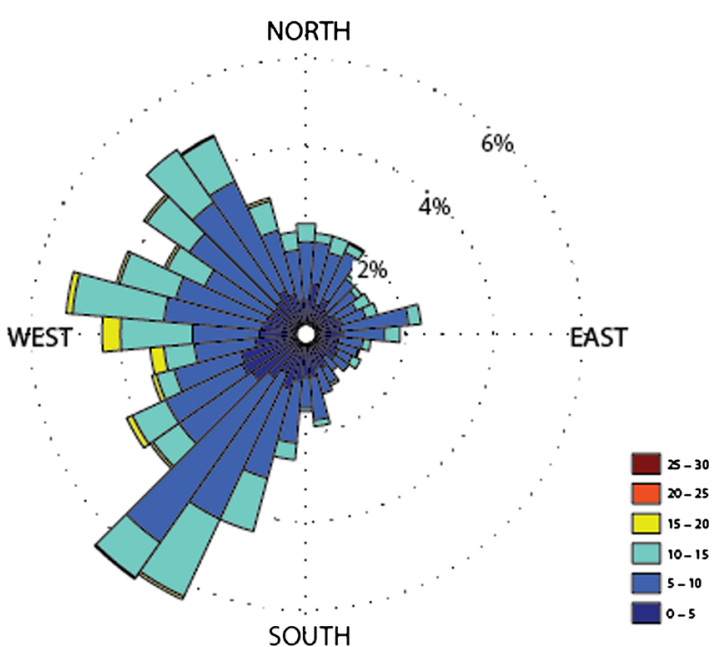

Jan-April 2012 hourly wind data

Fig. 4 Wind rose diagrams using hourly NDBC buoy 44025 data from a 1993-2012 and b January-April 2012. Concentric circles represent percentage of occurrence and colors denote wind speeds. Directions are "winds from"

east, as currents from these winds are assumed to be the predominate mechanism for the SFCR maintenance mechanisms.

Full data sets from most sites were not available because of instrument failures. For the purposes of this investigation, we will focus on the ocean currents and sediment observations from sites 1,2 , and 3 . For all the analyses, the winds and currents were rotated $10^{\circ}$ anticlockwise to determine alongshore and cross-shore directions, with these orientations as shown in Fig. 1. Some of the quantities presented have also been lowpass (30-h cutoff frequency) filtered to remove the tidal variability.

The wind varied greatly in the alongshore and crossshore directions with speeds occasionally reaching near $15 \mathrm{~ms}^{-1}$ (Fig. 5a). Significant wave heights peaked near $3 \mathrm{~m}$ during several of the stronger storms and rarely dropped below $0.5 \mathrm{~m}$ (Fig. 5b). The wave heights are typically correlated with local winds but can have a component from distant swell. During the deployment, the tidal range almost reached $2 \mathrm{~m}$ during spring tides and less than $1 \mathrm{~m}$ during neap tides, with an average tidal range on the order of $1.2 \mathrm{~m}$ (Fig. 5c). Low frequency oscillations are apparent (Fig. 5c red line), especially during February 26 when winds were from the northwest at over $15 \mathrm{~ms}^{-1}$, creating a sea level setdown along the coast. The currents varied tidally, with a strong meteorological influence. The tidal component reached up to $0.25 \mathrm{~ms}^{-1}$ in the near-surface currents (not shown) and up to $0.15 \mathrm{~ms}^{-1}$ in the nearbottom currents (Fig. 5d). The nontidal wind-driven component can vary up to $0.20 \mathrm{~ms}^{-1}$ (Fig. $5 \mathrm{~d}$ red line). In the cross-shore, the currents were weaker and on the order of $0.15 \mathrm{~ms}^{-1}$ but also contained tidal and stormdriven components. The nontidal variability of the ocean currents are analyzed in the next section.

\subsection{Alongshore currents}

The coastal currents exhibit a strong tidal variability but are also significantly modulated by local winds. For example, winds from the northeast will predominately drive currents toward the southwest. This can be seen by comparing the winds and near-bottom currents at site 1 . The filtered time series of the alongshore winds and currents (Fig. 6) show a strong correlation $\left(R^{2}=0.67\right)$. Responses for surface currents at site 1 and near-bottom and surface currents at site 2 (not shown) are similar, with the dominant alongshore currents driven by the wind. This is in agreement with the idealized scenario shown in Fig. $2 b$ and in the momentum balance as shown in Fig. 3 (left panels) in which the alongshore balance is dominated by the surface stress term driving the flow.

\subsection{Cross-shore currents}

The cross-shore currents are typically expected to have an influence from the cross-shore component of the wind, but these observations demonstrate a stronger correlation with the alongshore component of the wind (Fig. 7). The variability of the cross-shore currents is correlated higher to the alongshore winds with a correlation of $R^{2}=0.40$ than the correlation of the cross-shore currents to the cross-shore winds with a correlation of only $R^{2}=0.05$ (not shown). Periods of reduced correlation between cross-shore currents and alongshore winds coincide with periods of stronger cross-shore wind speeds, but in general, the cross-shore currents appear to be more 
Fig. 5 Time series of weather observations from site 1 and oceanographic observations from site 2 from January to April 2012. a Alongshore and cross-shore wind speeds (see Fig. 1 for directions), b significant wave height, $\mathbf{c}$ water level, $\mathbf{d}$ alongshore near-bottom currents, and e crossshore near-bottom currents. Red line in panels $\mathbf{c}-\mathbf{e}$ are low-pass filtered
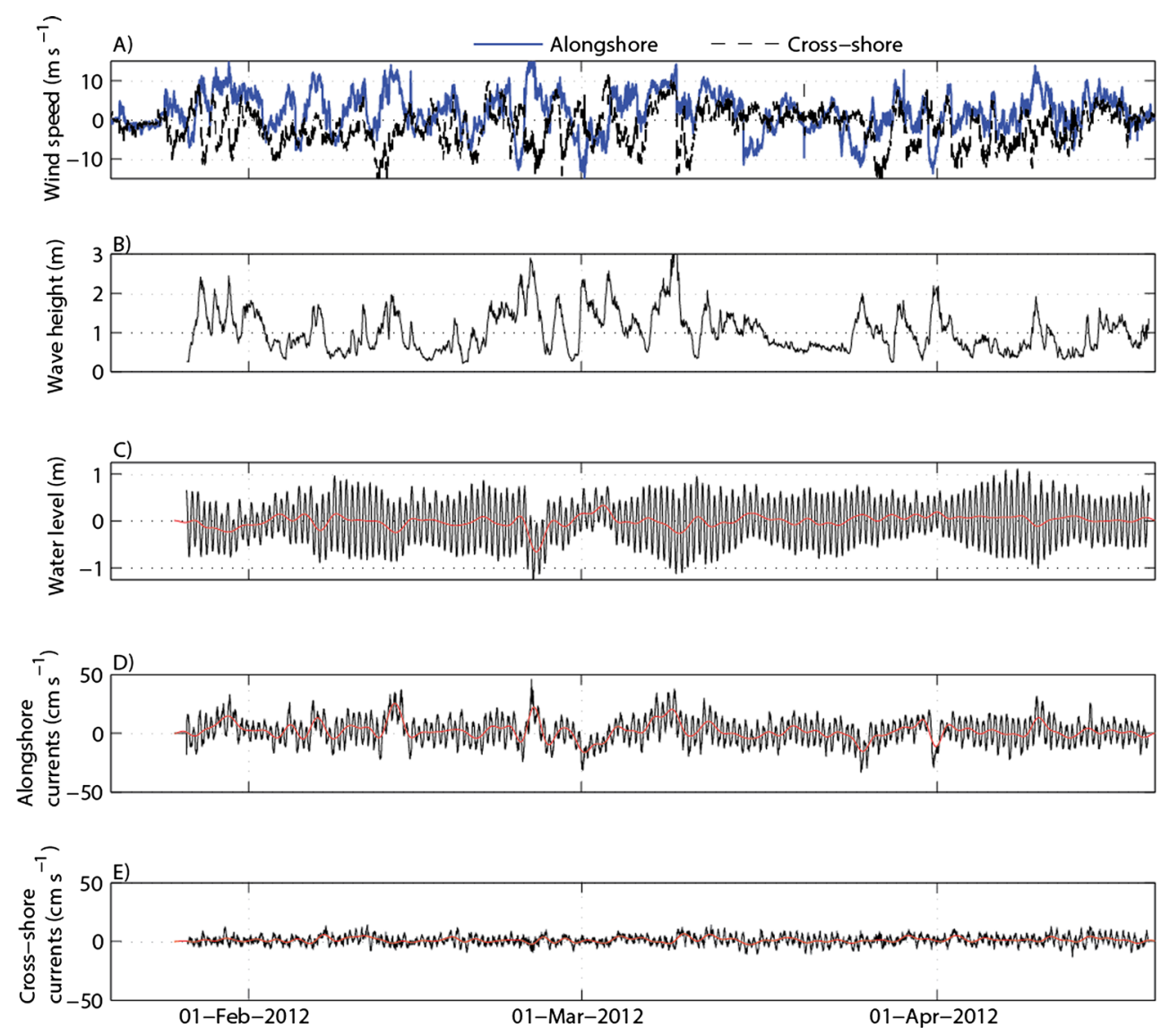

strongly modified by the alongshore winds than the crossshore winds for this observed time period.

The previously published stability analysis results and the limited numerical results presented in the last section suggest that the alongshore flows are deflected over the ridges. For the configuration along Fire Island, when the winds are from the northeast (negative alongshore direction), the currents should be deflected offshore over the ridges and onshore in the troughs. When the winds are in the opposite direction, we should expect to observe a reverse flow pattern (i.e., onshore deflection of currents over the ridges). To evaluate these trends, we examine the measured variability of the crossshore currents collected at sites 1 (crest), 2 (trough), and 3 (crest) (Fig. 8). When the winds are from the northeast, the winds are in the negative alongshore direction and this would drive an offshore (negative) current on the crest (site 1) and onshore (positive) current in the trough (site 2). The difference in the cross-shore currents between these sites (negative offshore at site 1 minus positive onshore at site 2) should therefore be negative and increase in magnitude as the wind speed increases in the negative direction (Fig. 8a). When the winds are from the southwest (in the positive alongshore direction), the currents on the crest (site 1) should be in the onshore direction (positive) and currents in the trough should be directed offshore (negative). The difference between these cross-shore currents should be positive (positive onshore at site 1 minus negative offshore at site 2). The observations exhibit this trend (Fig. 8a), and the difference in cross-shore current between the sites correlates with the speed of the wind.

Contrastingly, the differences between the cross-shore currents from site 2 (trough) to site 3 (the next crest) should trend in the opposite sense (Fig. 8b). When the wind is from the
Fig. 6 Comparison of filtered alongshore wind speed to alongshore near-bottom currents at site $1 . R^{2}=0.67$

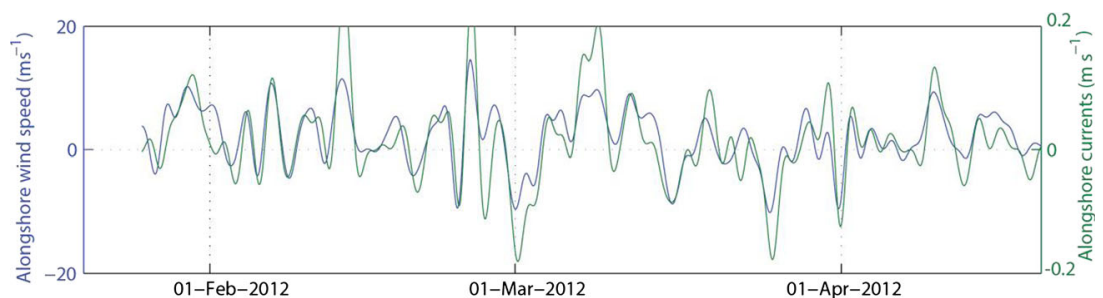


Fig. 7 Comparison of filtered alongshore wind speed to crossshore near-bottom currents at site 1. $R^{2}=0.40$

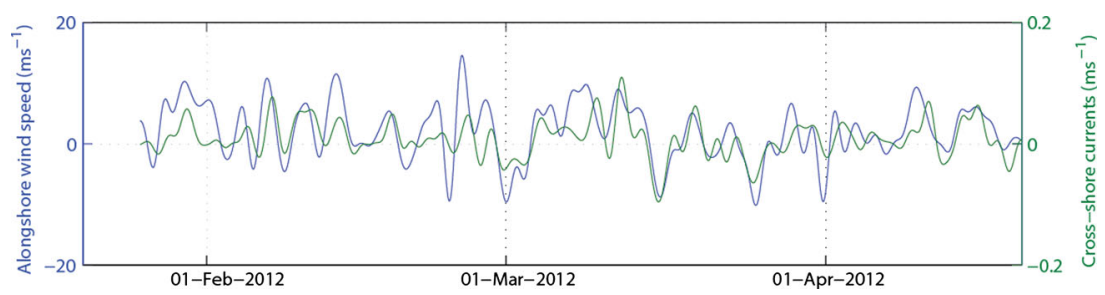

northeast, the trend should be for the difference in the onshore currents in the trough (site 2) minus the offshore currents at the crest (site 3) to be positive, and the opposite for the positive alongshore winds. These patterns are also reflected on the observed data confirming the circulation on the SFCRs as described by our simplified model analysis.

\subsection{Near-bottom suspended sediment concentrations}

The response of the suspended sediment dynamics over the ridges can be analyzed to determine the mobility of the sediment at the observation sites. Typically, the sediment on the inner shelf is mobile during storm events when the combined bottom stress from waves and currents increases beyond a critical threshold value for mobility. At each instrument site, surficial sediment samples were obtained using a Van Veen-type grab sampler. The samples were sieved to determine a grain size distribution following the methodology outlined in Poppe et al. (1985). Results show a relatively consistent range of distributions at each site with grain sizes ranging from $\sim 0.125 \mathrm{~mm}(3 \phi)$ to $\sim 1.0 \mathrm{~mm}(0 \phi)$, with a mean size from all sites of $d_{50}=0.25 \mathrm{~mm}(2 \phi)$. Sediment is mobilized primarily due to bottom stress from waves, as shown in Fig. 9. The bottom stress, expressed as a shear velocity $u *$, was computed using Madsen (1994) with locally measured waves from the acoustic Doppler current profiler (ADCP) and near-bed currents from the ADVs at sites 1 and 2 , and a grain size based on $d_{50}$. The shear velocity from the mean currents alone $(u * c$, green line), waves alone $(\mathrm{u} * \mathrm{~W}$, black line), and the shear velocity for the combined maximum wave and currents $(\mathrm{u} * \mathrm{Wm}$, red line) are shown in Fig. $9 b$. The stress from the currents $u_{*} \mathrm{c}$ is typically weaker than that from the waves and can be seen to vary tidally, especially during the stronger storm event near March 9, 2012. The waves provide most of the shear stress on the sea bed with the combined wave and current stress showing some enhancement due to the increased current strength during specific storm events. Based on Soulsby and Whitehouse (1997), the shear velocity required to mobilize the finest grain size $(2 \phi)$ is $0.014 \mathrm{~ms}^{-1}$ (horizontal dashed black, Fig. 9b). There are a few instances when the current stress alone is strong enough to resuspend the sediment. However, the typical occurrence is that the wave stress is the dominant mechanism for creating sediment mobility.

Data from the ABS identified several sediment suspension events during the deployment. These events correspond to time when $\mathrm{u} * \mathrm{Wm}$ exceeded the critical value for mobility (Fig. 9a, b). At these times, the sediment concentrations increased throughout the water column, with the strongest signal near the seafloor. Several events near the end of February through the middle of March measured near-bed concentrations reaching nearly $0.5 \mathrm{~kg} \mathrm{~m}^{-3}$. The instrument was mounted about $1 \mathrm{~m}$ above the seafloor and looked downward, and the seabed is identified with the strong (red color) return signal. Distance to the seafloor started at nearly $1.15 \mathrm{~m}$ and varied over time. The distance decreases near the storms at the end of February and
A)

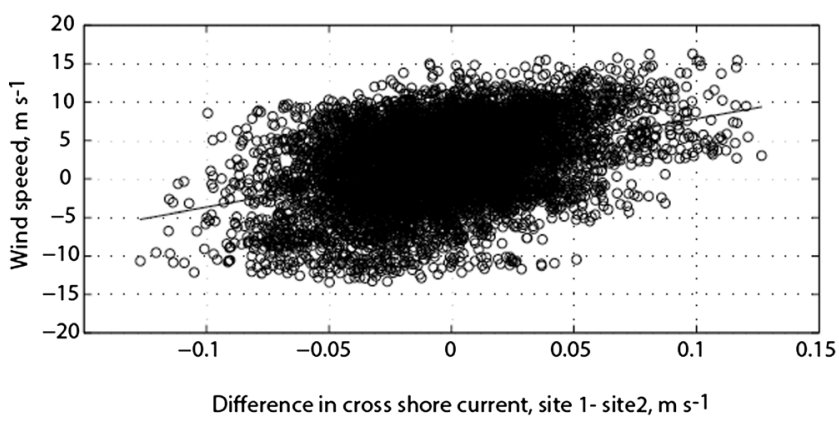
Crest (site 1)
B)

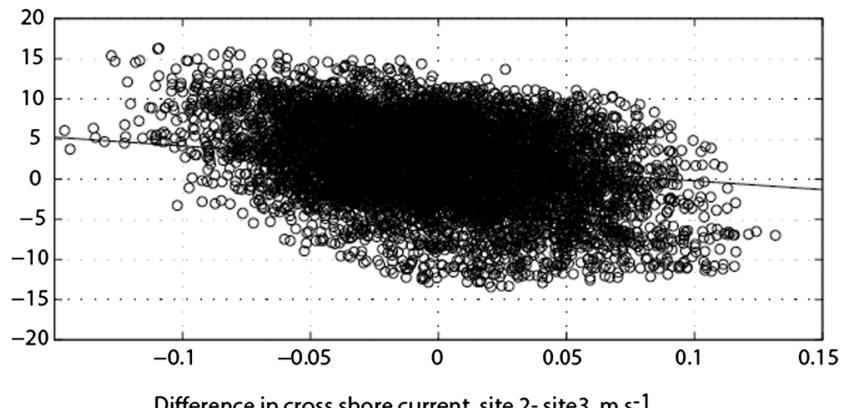

Trough (site 2)

Fig. 8 Difference in cross-shore near-bottom currents from a site 1-site 2 and $\mathbf{b}$ site 2-site 3 
Fig. 9 Time series from site 1. a Vertical profiles of suspended sediment concentrations. Note darker red region identifies the sea floor. b Calculated bottom stresses from currents, waves, and combined wave-currents. Dashed line denotes critical velocity for resuspension

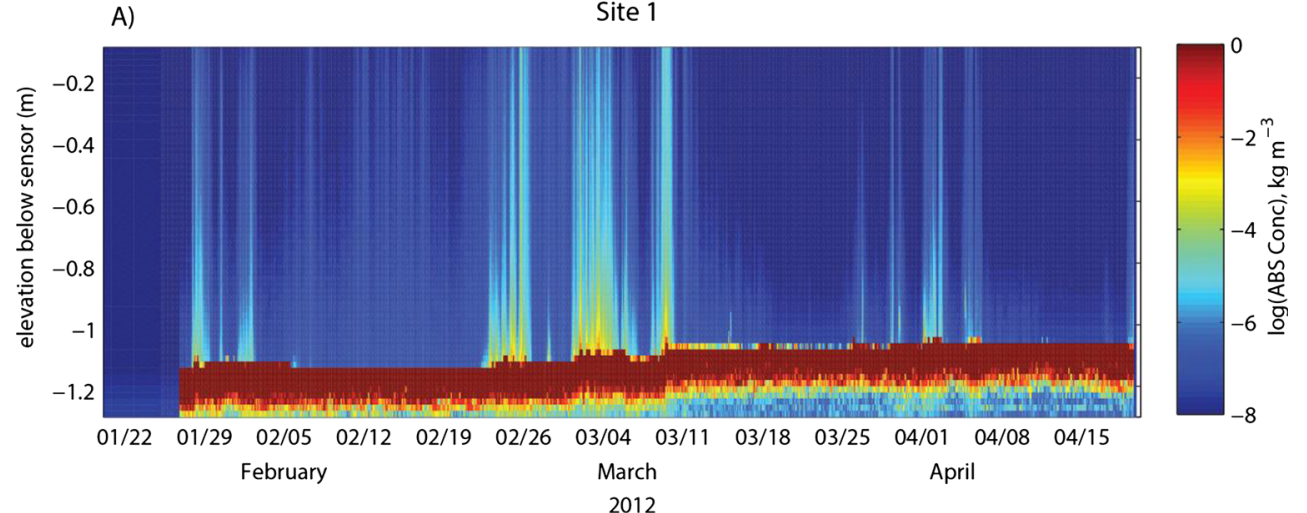

B)

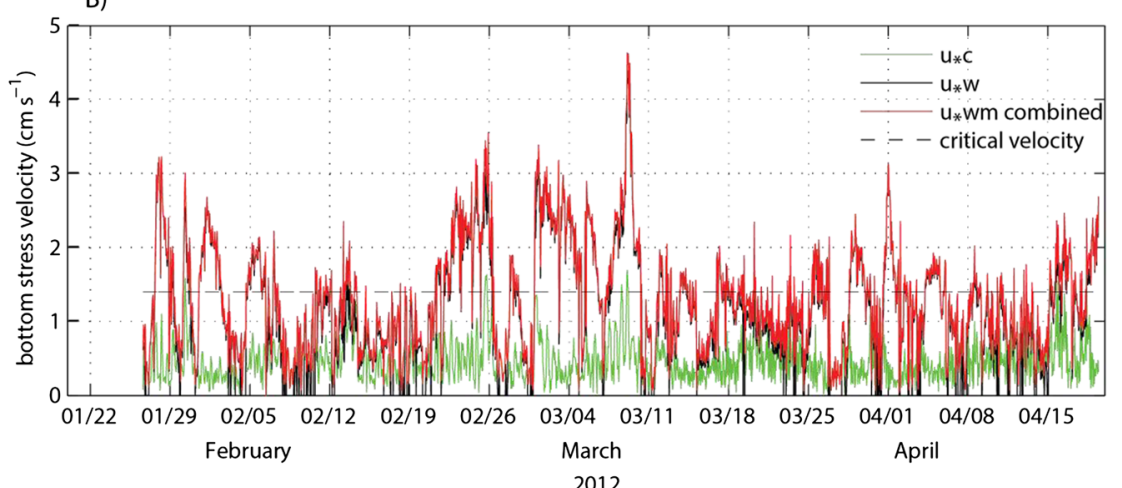

beginning of March 2012. This could be due to bedforms migrating under the tripod or due to the tripod settling into the seafloor. Instruments at site 2 (not shown) observed a similar response, with the same order of magnitude of concentrations and a similar seabed change.

\subsection{Seafloor bedform morphology}

Changes to the seafloor ripples during the different storm events indicated mobility of sediment on the seafloor. Data from the downward-looking rotating sonar at site 1 that scanned the seafloor identified variations of ripple geometry. Unfortunately, the sonar at site 2 flooded and did not return any data. During the deployment, storm wave heights reached near $3 \mathrm{~m}$ at the observation sites (Fig. 10a), with wave events occurring every 2-3 days. The mean wave periods, as measured by the ADCP at $25 \mathrm{~m}$ depth, were typically between 4 and $8 \mathrm{~s}$, showing strong influence from the locally generated winds (Fig. 10b). However, the peak periods ranged from 4 to $14 \mathrm{~s}$. The maximum peak periods often occur at the end of the storms when the wave heights are decreasing but are comprised predominately of remotely generated swell with longer periods. The largest peak period was near $14 \mathrm{~s}$ on March 6, 2012 (Fig. 10b), occurring when the waves were relatively small. This event was remotely generated, and even though the wave heights were small
( $\sim 1.5 \mathrm{~m}$, Fig. 10a), it induced a bottom shear velocity of nearly $3 \mathrm{cms}^{-1}$ (Fig. 9b), comparable to most of the other events which had higher wave heights. However, it will be shown to produce a relatively small suspended sediment flux (next section) because the winds were light and the alongshore currents were dominantly tidally driven at that time.

The mean wave directions are controlled by the combination of the wind waves and distant swell (Fig. 10c). The directions varied during each storm and ranged from $100^{\circ}$ to $270^{\circ}$ but typically were from a southerly direction. As the wave direction varied, so did the seabed ripples, indicating local bed reorganization similar to the processes described in Nelson and Voulgaris (2014). Gray shaded boxes in Fig. 10 identify three different storm events that will also be discussed for the suspended sediment fluxes in the next section. On February 25, 2012, there was a small storm with waves from approximately $120^{\circ}$ and the seafloor ripples migrated to align with that predominant direction. The storm on February 26 is the passage of a cold front, with winds that are mostly from the southwest. This event rotates the seafloor ripples to be directed toward the northeast. The next storm event was a type of low-pressure system to the south of the study region that drove winds from the northeast near March 3. After this event, the seafloor ripples reorientated themselves toward $120^{\circ}$ as seen on March 4 . The third storm was another cold front passing through on March 8 and 


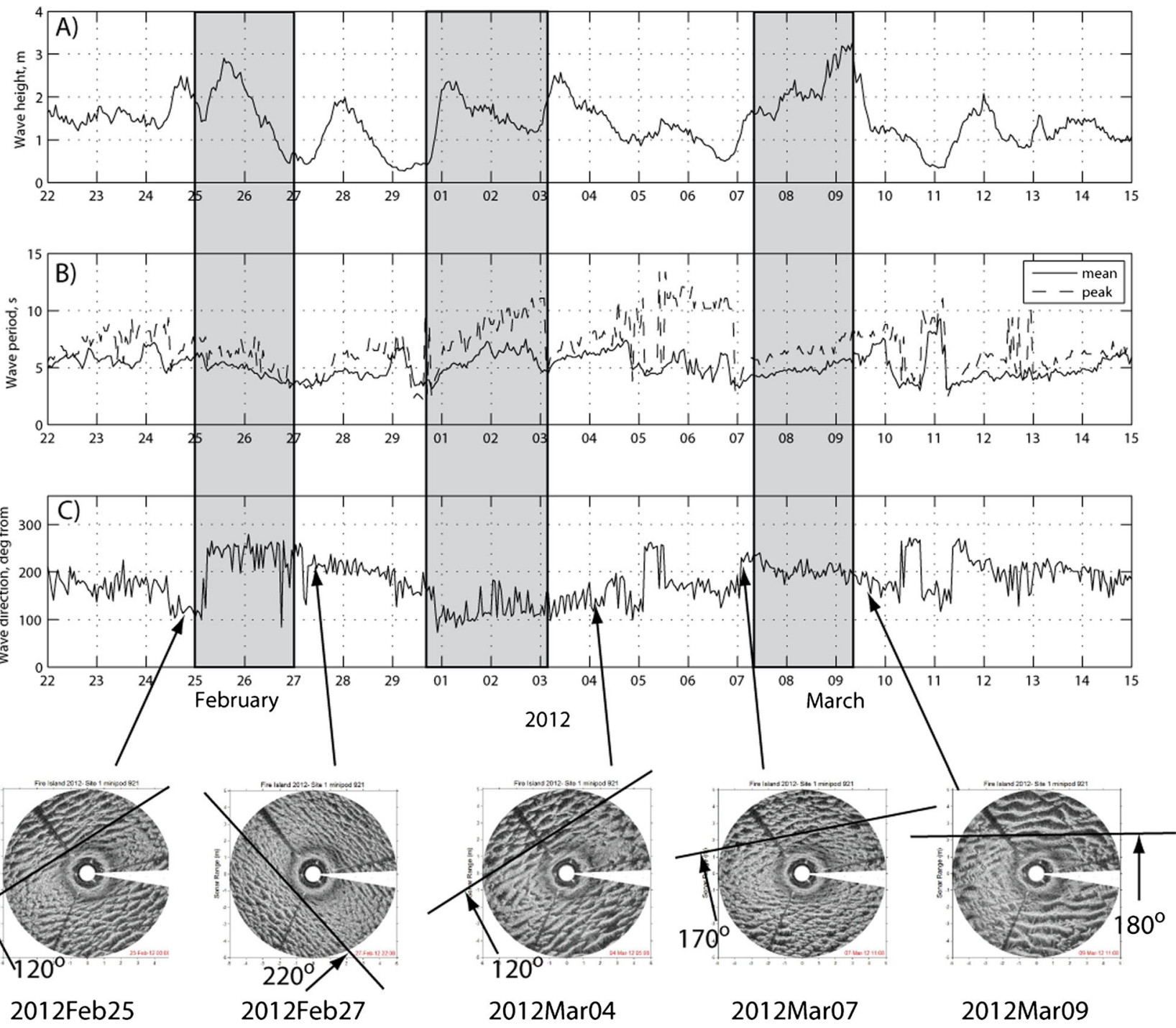

Fig. 10 Time series of a significant wave height, $\mathbf{b}$ mean and peak wave periods, and $\mathbf{c}$ mean wave direction during several storm events. Lower row contains sonar images showing seafloor ripples and crest perpendicular direction. Gray shaded boxes identify three different storm events also shown in Fig. 11

reorientated the ripples to be directed onshore. These sequences of sonar images (Fig. 10) identify that the seafloor is mobile in $20 \mathrm{~m}$ of water depth during these relatively minor storms.

\section{Discussion}

The simplified idealized numerical modeling presented in Section 2 and the analysis of the observational data in Section 3 support the circulation dynamics described previously using stability analysis. In this contribution, we do not address the issue of ridge generation but the actual ridge maintenance and migration features that are governed by the sediment dynamics that are controlled by the combination of waves and currents. When the currents across the ridge crests are turned offshore into deeper water, their sediment-carrying capacity will decrease slightly, promoting deposition of sediment onto the ridge crests and creating ridge growth. The ridge migration rates are dependent on the alongshore currents that will translate the entire features along the coast.

Measurements obtained from the recent field deployment can be analyzed to investigate if the SFCRs are inducing these self-maintaining sediment fluxes. During the deployment, the sediment was primarily mobile only during the storm events. Focusing on these events, we can analyze instances when the wind was from the northeast and contrast that to the SFCR maintenance theory. Additionally, there are instances when the currents and sediment fluxes are in other directions and sometimes showing a reversing sediment flux pattern. There were only a few strong storm events, and this limited our 
ability to observe the sediment mobility and response. Most of these events occurred near the end of February and the beginning of March 2012 and are the focus of the discussion.

Suspended sediment fluxes were computed from the vertical integral of the ABS-suspended sediment concentration profiles multiplied by the lowest bin of the upward-looking ADCPs at both sites 1 and 2. The lowest bin was typically about $2 \mathrm{~m}$ above the sea floor, and the ABS profiles were measured over the bottom $1 \mathrm{~m}$.

For the storms that were observed, the same three events that were identified and described previously are used to demonstrate SFCR sediment flux processes (Fig. 11, gray shaded regions). One storm included winds mainly from the northeast and two other storms had winds that were predominately from the southwest. The storm with wind from the northeast occurred during the passage of a low-pressure system from March 1-3, 2012. The low-pressure system was southwest of the site and traveled toward the northeast, passing to the north of the site (center graphic bottom of Fig. 11). The winds had a variable heading starting from $90^{\circ}$, rotating counterclockwise to $360^{\circ}$, and then back to $90^{\circ}$. During this time, the wind speed increased from approximately $8 \mathrm{~ms}^{-1}$ to near $13 \mathrm{~ms}^{-1}$, then reduced to approximately $8 \mathrm{~ms}^{-1}$ again (Fig. 11, panels a and b). During this storm, the computed net alongshore sediment fluxes (red lines) were toward the southwest for both site 1 (Fig. 11c) and site 2 (Fig. 11d). This is consistent with the currents and net sediment fluxes in the direction of the alongshore winds. However, the cross-shore fluxes at the two sites are in opposing directions. At site 1, the cross-shore sediment flux is offshore, and at site 2 , it is onshore (black lines in gray shaded region, Fig. 11c, d). This is consistent with the SFCR maintenance mechanism theory of offshore-deflected currents over the ridge crests (site 1) and onshore in the troughs (site 2).

As the low-pressure storm continued to move past the site to the north, the alongshore winds rotated to be from the southwest and the cross-shore winds became the dominant forcing mechanism. These offshoredirected winds were heading from approximately $330^{\circ}$ and forced a type of upwelling response near March 4, 2012 (Fig. 11c, d, non-shaded portion in the black outlined box). During this time period, the winds drove net suspended sediment fluxes in the positive alongshore direction toward the northeast and landward in the cross-shore direction at both sites. This created a situation that is not characterized as a SFCR maintenance response, but it was a measurable response on the inner shelf.

Other types of storm events produced different responses, such as the two events centered on February 26 and March 8, 2012 (gray shaded regions, Fig. 11).
These occurred as cold fronts that moved across the study area. The responses from each of these cold fronts were slightly different to each other, based on criteria such as their strength, angle toward the coastline, and proximity to the driving low-pressure system to the north. However, there were also some strong commonalities. During both of these events, the wind speed reached over $15 \mathrm{~ms}^{-1}$ and winds were initially directed from the west from approximately $300^{\circ}$ for the first cold front and from $250^{\circ}$ for the second cold front. These alongshore winds were equivalent to, or stronger than, the cross-shore winds (gray shaded regions near February 26 and March 8, Fig. 11a). During both of these cold front events, the alongshore sediment fluxes were toward the northeast in the direction of the alongshore winds at both sites (red lines, Fig. 11c, d). On February 26, the alongshore sediment flux reached nearly $0.3 \mathrm{~kg} \mathrm{~m}^{-2} \mathrm{~s}^{-1}$ at both sites 1 and 2 and was toward the northeast in the direction of the surface stress. On March 8, the alongshore sediment fluxes at both sites were again toward the northeast in the direction of the winds, this time exhibiting a tidal response. During these cold fronts, however, the cross-shore directions of the sediment fluxes were divergent. At site 1, the fluxes were in the onshore direction (black line, Fig. 11c) for both events on February 26 and March 8, 2012. At site 2, the fluxes were in the offshore direction (black line, Fig. 11d) for both of these events. The cross-shore sediment flux magnitudes were smaller on the order of nearly $0.1 \mathrm{~kg} \mathrm{~m}^{-2} \mathrm{~s}^{-1}$. This is consistent with the concept that the flow over the SFCRs during a wind reversal would drive the opposite pattern of circulation and suspended sediment fluxes.

Additionally, on March 9, 2012, the alongshore winds became weak and the cross-shore winds dominated the pattern (Fig. 11a, red line in the non-shaded region in the black box). These offshore winds again created another upwelling-type scenario that drove an alongshore sediment flux toward the northeast. In the cross-shore direction, there was an offshore flow at the surface and near the bed a net onshore and suspended sediment flux in the onshore direction. This again is not suggested from the stability analysis as a SFCR maintenance process but is a type of response that was observed during the deployment.

The net long-term maintenance of the ridges would be dictated by the long-term climatology of the region. The 20 years of wind data from the NDBC buoy 44025 (Fig. 4a) shows that the winds are more prevalent from the southwest, but the strongest winds come from both the west-northwest and from the northeast. These winds from the northeast can generate strong alongshore currents and thus can provide a mechanism 

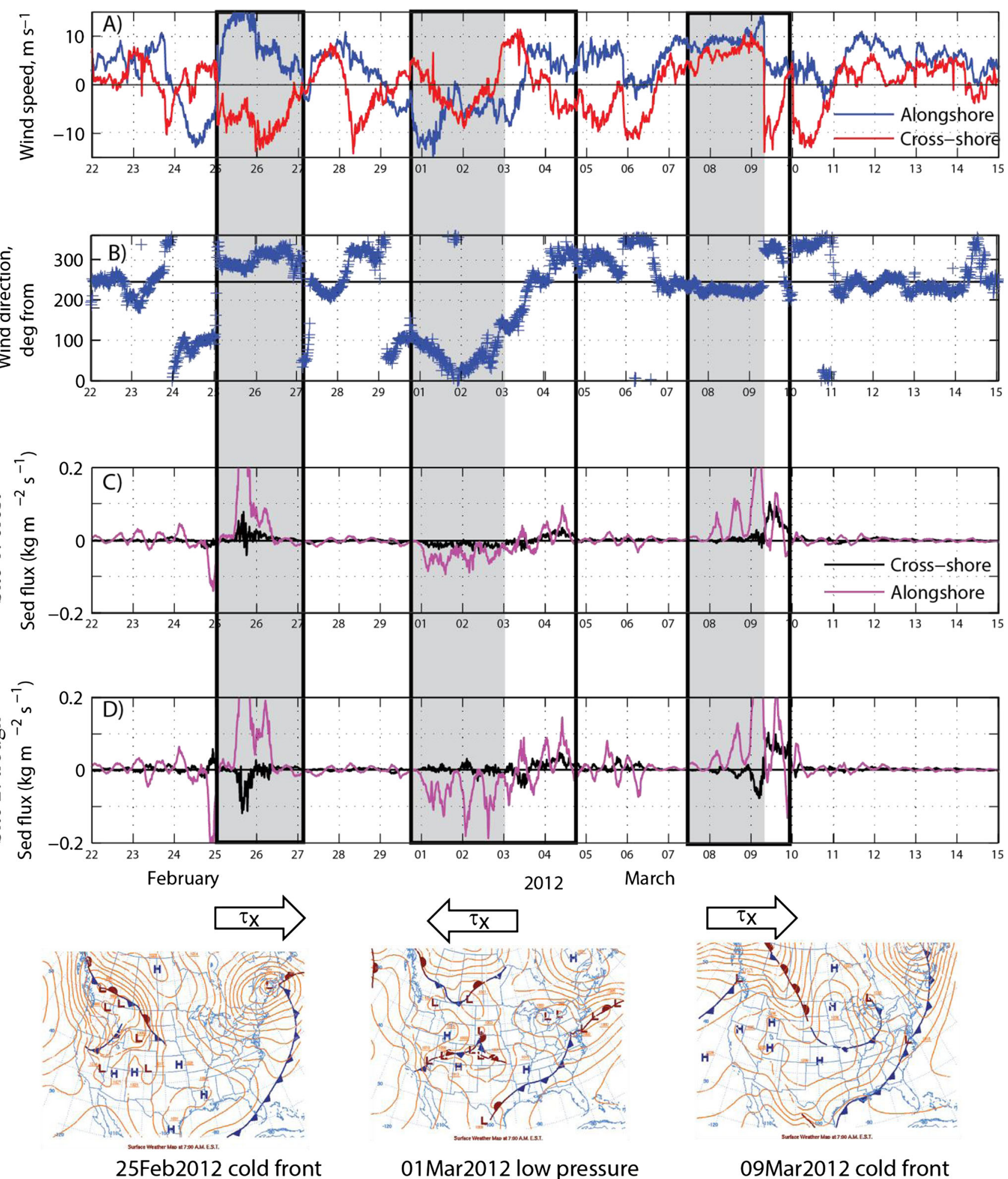

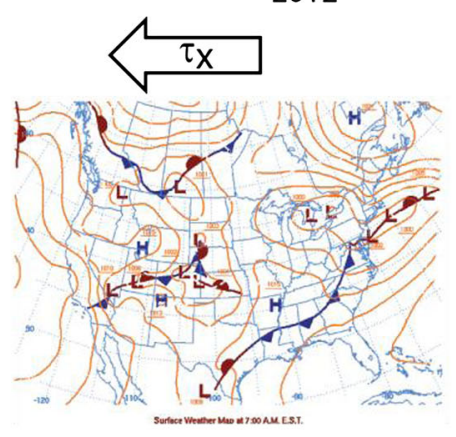

01 Mar2012 low pressure

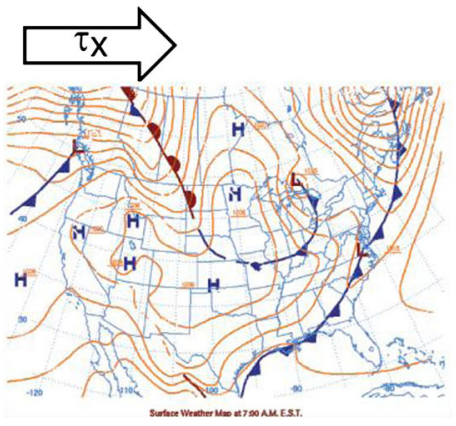

09Mar2012 cold front
Fig. 11 Time series of a wind speed, $\mathbf{b}$ wind direction, and suspended sediment fluxes at $\mathbf{c}$ site 1 and $\mathbf{d}$ site 2 . Alongshore sediment fluxes (red) are positive toward the northeast, and cross-shore sediment fluxes (black) are positive onshore. Gray shaded boxes identify three different storm events also shown in Fig. 10 to sustain the development and maintenance of the SFCR features. However, we have shown that the opposite and offshore wind patterns do occur and drive flows and sediment flux patterns that are different than the processes that in theory support the SFCR maintenance. The long-term maintenance is a function of the 
combination of all these types of events and of sediment availability.

\section{Summary and conclusions}

Shoreface-connected ridges are sedimentary features located on the inner shelves at many locations worldwide, characterized as sand bodies orientated obliquely to the coastline on microtidal shelves with a predominant wind-driven flow regime. We investigated the circulation and possible maintenance mechanisms of these features on the inner shelf offshore of Fire Island, NY. A recent USGS field mapping cruise provided higher resolution data and showed that these features are approximately $10 \mathrm{~km}$ long, spaced on the order of $3 \mathrm{~km}$ apart, have a maximum crest to trough relief on the order of $\sim 8 \mathrm{~m}$, and oriented oblique from the coastline.

A series of numerical experiments were performed to identify the oceanographic circulation across a series of idealized SFCRs scaled to match the configuration of the in situ features. Alongshore flows driven by a surface stress with the offshore deflection of the SFCR features angled upwind will develop an offshore-directed flow on the crests and onshore in the troughs, being consistent with previous stability analysis approaches that demonstrate ridge growth and maintenance. Winds from the opposite direction drive a reverse flow pattern, with flows onshore on the crests and offshore in the troughs. The momentum balance is used to characterize the dominant flow terms showing that the acceleration of flow over the shoals requires an offshore transport for mass balance and this creates the veering of the currents over the crest.

Observations at several sites offshore of Fire Island for nearly 4 months (January to April 2012) were analyzed, and patterns of flow over the SFCRs were identified that are consistent with the numerical experiments for winds from different directions. The strongest observed event occurred with a wind speed of approximately $15 \mathrm{~ms}^{-1}$, which is approximately a surface stress of $0.4 \mathrm{~Pa}$, the value used in the idealized study. Suspended sediment fluxes computed from observations identify the SFCR maintenance fluxes but also show other transports such as onshore-directed sediment fluxes during offshore wind events driving upwelling-type flows. The long-term maintenance of the SFCRs depends on the continuation of the climate history that created the ridges and a continued sediment supply.

\footnotetext{
Acknowledgments This research was funded by the U.S. Geological Survey, Coastal and Marine Geology Program, and conducted by the Coastal Change Processes Project. This data collection and interpretation was largely a collaborative effort between the U.S. Geological Survey and the University of South Carolina. We acknowledge support from the Woods Hole Oceanographic Institution Summer Student Fellowship Program. We appreciate the assistance from the crew aboard the $\mathrm{R} / \mathrm{V}$ Connecticut to deploy and recover oceanographic
}

instruments and we thank USGS field technicians Marinna Martini, Jonathan Borden, Ellyn Montgomery, Sandy Baldwin, Dann Blackwood, and Chuck Worley.

Open Access This article is distributed under the terms of the Creative Commons Attribution License which permits any use, distribution, and reproduction in any medium, provided the original author(s) and the source are credited.

\section{References}

Calvete D, Falqués A, de Swart HE, Walgreen M (2001a) Modeling the formation of shoreface-connected sand ridges on storm-dominated inner shelves. J Fluid Mech 441:169-193

Calvete D, Walgreen M, de Swart HE, Falqués A (2001b) A model for sand ridges on the shelf: effect of tidal and steady currents. J Geophys Res 106(C5):9311-9325

Duane DB, Field ME, Meisburger EP, Swift DJP, and Williams SJ. (1972) Linear shoals on the Atlantic inner shelf, Florida to Long Island, IN Swift, D.J.P., Duane, D.B., and Pilkey, O.H., eds., Shelf sediment transport: Stroudsburg, Pennsylvania, Dowden, Hutchinson, and Ross, p. 447-489

Falques A, Calvete D, de Swart HE, and Dodd N (1998) Morphodynamics of shoreface-connected ridges. In: Proc. ICCE Copenhagen, Vol 3, June 22-26, 1998, Copenhagen, Denmark, 2851-2864

Figueiredo AG, Sanders JE, Swift DJP (1982) Storm-graded layers on inner continental shelves: examples from Southern Brazil and the Atlantic coast of the central US. Sed Geol 31:171-190

Haidvogel DB, Arango HG, Budgell WP, Cornuelle BD, Curchitser E, Di Lorenzo E, Fennel K, Geyer WR, Hermann AJ, Lanerolle L, Levin J, McWilliams JC, Miller AJ, Moore AM, Powell TM, Shchepetkin AF, Sherwood CR, Signell RP, Warner JC, Wilkin J (2008) Ocean forecasting in terrain-following coordinates: formulation and skill assessment of the Regional Ocean Modeling System. J Comput Phys 227:3595-3624

Hapke CJ, Lentz EE, Gayes PT, McCoy CA, Hehre R, Schwab WC, Williams SJ (2010) A review of sediment budget imbalances along Fire Island, New York: can nearshore geologic framework and patterns of shoreline change explain the deficit? J Coast Res 26(3): $510-522$

Hoogendoorn EL, Dalrymple RW (1986) Morphology, lateral migration and internal structures of shore-face connected ridges, Sable Island Bank, Nova Scotia, Canada. Geology 14:400-403

Huthnance JM (1982) On one mechanism forming linear sand banks. Estuar Coast Shelf Sci 14:79-99

Lane EM, Restrepo JM (2007) Shoreface-connected ridges under the action of waves and currents. J Fluid Mech 582:23-52

Leatherman SP (1985) Geomorphic and stratigraphic analysis of Fire Island, New York. Mar Geol 63:173-195

Madsen OS (1994) Spectral wave-current bottom boundary layer flows. Coastal Engineering 1994. Proceedings, 24th International Conference, Coastal Engineering Research Council / ASCE, 384 398

Martini MA, Warner JC, List JH, Armstrong BA, and Montgomery E, and Marshall N (2012) Ocean circulation and sediment transport experiment offshore of Fire Island, NY. Oceans, MTS/IEEE, Hampton Roads, VA, Oct 14-19, 2012, p1-8

Nelson TR, Voulgaris G (2014) Temporal and spatial evolution of waveinduced ripple geometry: regular versus irregular ripples. J Geophys Res Oceans 119:664-668. doi:10.1002/2013JC009020

Nnafie A, de Swart HE, Calvete D, Garnier R (2014a) Modeling the response of shoreface-connected sand ridges to sand extraction on 
an inner shelf. Ocean Dyn 64(5):723-740. doi:10.1007/s10236014-0714-9

Nnafie A, de Swart HE, Calvete D, Garnier R (2014b) Effects of sea level rise on the formation and drowning of shoreface-connected sand ridges, a model study. Cont Shelf Res 80:32-48

Parker G, Lanfredi NW, Swift DJP (1982) Seafloor response to flow in a Southern Hemisphere sand-ridge field: Argentina Inner Shelf. Sed Geol 33:195-216

Poppe LJ, Eliason AH, and Fredricks JJ (1985) APASA-An Automated Particle Size Analysis System: U.S. Geological Survey Circular, 963, $7 \mathrm{p}$

Schwab WC, Baldwin WE, Hapke CJ, Lentz EE, Gayes PT, Denny JF, List J, Warner JC (2013) Geologic evidence for onshore sediment transport from the inner continental shelf: Fire Island, New York. J Coast Res 29(3):526-544

Shchepetkin AF, McWilliams JC (2005) The Regional Oceanic Modeling System: a split-explicit, free-surface, topography-following coordinate oceanic model. Ocean Model 9:347-404. doi:10.1016/j. ocemod.2004.08.002

Shchepetkin AF, McWilliams JC (2009) Correction and commentary for "Ocean forecasting in terrain-following coordinates: formulation and skill assessment of the regional ocean modeling system" by Haidvogel et al., J. Comp. Phys. 227, pp. 3595-3624. J Comput Phys 228:8985-9000
Soulsby RL. and Whitehouse RJS (1997) Threshold of sediment motion in coastal environments. Proc. Combined Australasian Coastal Engineering and Ports Conference, Christchurch, 1997

Swift DJP, Holliday B, Avignone N, Shideler G (1972) Anatomy of a shoreface ridge system, False Cape, Virginia. Mar Geol 12:59-84

Swift DJP, Parker G, Lanfredi NW, Perillo G, Figge K (1978) Shorefaceconnected sand ridges on American and European shelves: a comparison. Estuar Coast Mar Sci 7:257-273

Thorne PD, Campbell SC (1992) Backscattering by a suspension of spheres. J Acoust Soc Am 92:978-986

Thorne PD, Hanes DM (2002) A review of acoustic measurement of small-scale sediment processes. Cont Shelf Res 22:603-632

Trowbridge JH (1995) A mechanism for the formation and maintenance of shore-oblique sand-ridges on storm-dominated shelves. J Geophys Res 100:16,071-16,086

Van De Meene JWH (1994) The shoreface connected ridges along the central Dutch coast, PhD Thesis, Netherlands Geographical Studies, 174

Vis-Star NC, de Swart HE, Calvete D (2007) Effect of wave-topography interactions on the formation of sand ridges on the shelf. J Geophys Res 112:C06012. doi:10.1029/2006JC003844

Walgreen M, de Swart HE, Calvete D (2003) Effect of grain size sorting on the formation of shoreface-connected sand ridges. J Geophys Res 108(C3):3063. doi:10.1029/2002JC001435 